\title{
Abnormal expression of Endoglin and its receptor complex (TGF-B1 and TGF-ß receptor II) as early angiogenic switch indicator in premalignant lesions of the colon mucosa
}

\author{
GRAZIELLA BELLONE $^{1}$, CLAUDIA GRAMIGNI ${ }^{1}$, BARBARA VIZIO ${ }^{1}$, FRANCESCO A. MAURI $^{2}$, \\ ADRIANA PRATI ${ }^{1}$, DINO SOLERIO ${ }^{1}$, LUCA DUGHERA $^{3}$, ENRICO RUFFINI ${ }^{1}$, \\ GUIDO GASPARRI $^{1}$ and MICHELE CAMANDONA ${ }^{1}$
}

\begin{abstract}
${ }^{1}$ Department of Clinical Physiopathology, University of Turin, Italy; ${ }^{2}$ Department of Histopathology, Hammersmith Hospital, London, UK; ${ }^{3}$ Motility and Endoscopy Unit, Department of Internal Medicine, San Giovanni Battista Hospital, Turin, Italy
\end{abstract}

Received April 16, 2010; Accepted June 21, 2010

DOI: 10.3892/ijo_00000767

\begin{abstract}
The precise timing of the angiogenic switch in colorectal cancer development is still unclear. The simultaneous expression of Endoglin (CD105), transforming growth factor (TGF)- $\beta 1$ and TGF- $\beta$ receptor (R) II were quantified in surgical specimens comprising normal human colon, pre-malignant dysplastic tissue, in situ, and invasive colon cancer specimens, at mRNA and protein levels, respectively by real-time PCR and immunohistochemistry. Serum concentrations of soluble Endoglin and TGF- $\beta 1$ were evaluated. mRNA and $\mathrm{CD}_{105^{+}-\text {microvessel density (MVD) }}$ increased significantly in dysplastic colon and carcinoma versus normal tissues; values correlated respectively with dysplasia degree and Dukes' stages. TGF-ß1 expression was significantly upregulated in most severe dysplastic adenoma specimens, while TGF- $\beta 1$ transcript and protein signals were intense in carcinoma, positively-correlated with tumor progression. TGF- $\beta 1$ RII was overexpressed in adenoma and carcinoma versus normal samples, but unrelated with dysplasia or Dukes' stage. Soluble Endoglin serum levels were equivalent in adenoma and normal tissues; in carcinoma the highest levels were in invasive tumor. Circulating TGF- $\beta 1$ levels were increased in severe dysplasia and progressed with tumor progression. Correlations between adenoma dysplasia degree and TGF- $\beta$ RII and CD105+-MVD, and between tumor Dukes' staging and TGF- $\beta 1$ and CD105+-MVD, were significant. TGF- $\beta 1$ and Endoglin and TGF- $\beta 1$ serum levels, TGF- $\beta 1$ staining and CD105+-MVD were significantly and inversely associated with disease-free survival. TGF- $\beta 1$ levels were an independent and significant prognostic factor of disease-free survival. These findings suggest active angio-
\end{abstract}

Correspondence to: Dr Graziella Bellone, Department of Clinical Physiopathology, University of Turin, Via Genova 3, I-10126 Torino, Italy

E-mail: graziella.bellone@unito.it

Key words: Endoglin, TGF- $ß 1$, TGF- $ß$ receptors, colon adenoma, colorectal carcinoma genesis occurs in many pre-malignant colon cases and supports more careful evaluation of different chemopreventive agents.

\section{Introduction}

Colon carcinoma is the third commonest form of cancer and the second cause of cancer-related death in the Western world, leading to 655,000 deaths worldwide per year (1). Despite the emergence of new targeted agents and the use of various therapeutic combinations, none of the treatment options available is curative in patients with advanced cancer.

Neoplastic conversion of human colorectal cells occurs in a stepwise fashion, leading from normal colonic epithelium to cancer (2). Despite the model adenoma-carcinoma sequence associated with an accumulation of genetic events (3), there are still no absolute criteria that can predict adenoma progression to cancer. Tumor angiogenesis is a critical step in the development, metastatic spread and regrowth of cancer. Tumors promote angiogenesis by secreting factors, including vascular endothelial growth factor (VEGF)-A, basic fibroblast growth factor (bFGF) and transforming growth factor (TGF)- 3 (4-6). Several reports suggest that an angiogenic switch may be activated in the premalignant stage of several human cancers (7-14).

TGF- $B$ is a multifunctional family of cytokines, which play a dual and paradoxical role in cancer: they can function as tumor suppressors in the early stages of epithelial tumorigenesis, having strong anti-proliferative, pro-apoptotic and tumor-growth-inhibiting effects; however, they can subsequently act as a tumor promoter factor, stimulating the epithelial-to-mesenchymal transition (EMT), invasiveness of cancer cells and inhibiting immune surveillance (15). Importantly, TGF- $\beta$ also plays an important role in angiogenesis by promoting proliferation and migration of endothelial cells at low concentrations, and leading to vessel maturation at high concentrations $(6,16)$. Furthermore, TGF- $\beta$ is known to induce VEGF expression (17). Genetic studies and knockout mice for the different components of the TGF- $\beta$ signaling pathway have shown that TGF- $\beta$ is indispensable for angiogenesis (18). TGF- $\beta 1$ is over-expressed in most human cancers (19). 
Three isoforms of the cytokine are recognized: TGF- $\beta 1$, TGF- 32 , and TGF- 33 ; each is encoded by a separate gene and has distinct in vivo functions (20). The core TGF- $\beta$ signaling pathway comprises type I [also known as the activin receptor-like kinase-5 (ALK5)] and type II receptors, where type I acts downstream of type II, and the combinatorial heterodimeric association of these receptors determines the specificity of the ligand signaling (21). Type III receptors (22) include the auxiliary molecules Endoglin and betaglycan.

Endoglin, designated as CD105, is a homodimer cellmembrane protein capable of fine-tuning the availability of TGF- $\beta$ to the signaling receptors, thereby determining the outcome of TGF-ß's biological activity (23). It has been demonstrated that Endoglin requires association with TGF- $\beta$ receptor (R) type II to bind ligands, and that it can interact with TGF- $\beta$ RI or RII in the absence of ligand (24). Based on different experimental data, it has been shown that Endoglin binds with high affinity to TGF- $\beta 1$ and TGF- 33 and, through its interactions with the TGF- $\beta$ R type I and type II, regulates their phosphorylation status and subsequently their signalling ability (25). Moreover, considerable experimental evidence shows that Endoglin is expressed at low levels in resting mature and immature endothelial cells, and that it is overexpressed in vascular endothelial cells of tissues undergoing active angiogenesis, such as regenerating and inflamed tissues, or tumors $(26,27)$. Furthermore, levels of Endoglin positively correlate with the extent of endothelial cell proliferation (28) and with the expression of proliferation markers in tumor endothelia (29). In addition, Endoglin/CD105 has been suggested to be the most suitable marker available to quantify tumor angiogenesis (30).

The expression profiles of Endoglin in association with TGF- $ß 1$ and its receptor have not been studied in colon premalignant lesions. We decided to analyze comparatively the expression of functional receptor complexes Endoglin/TGF-ß31/ TGF- $\beta$ RII, at successive stages of the colon normal-adenomacarcinoma sequence, to verify their role in tumor development and progression, providing the rationale for precautional therapeutic targeting opportunities.

\section{Patients and methods}

Patients. The study group comprised 75 patients who had received a diagnosis of colon adenoma $[n=32,22$ men, 10 women, aged median (range) 57 (32-77)], or adenocarcinoma [n=50, 25 men, 25 women, aged median (range) 61.5 (24-87)] at the Department of Clinical Physiopathology, Division of General Surgery (University of Turin, Turin, Italy) between January 2004 and June 2008. None had undergone anticancer treatment before entering the study, which was conducted under strict observance of the principles of the Declaration of Helsinki. Adenoma tissue specimens were obtained from endoscopic maneuvers and cancer specimens from surgical resections. All cancer patients had histopathologically-confirmed primary colorectal adenocarcinomas and were staged by Dukes' system, revised by Astler and Coller (31). Table I shows details of the patients and their diseases. Adenoma specimens were graded by patho-logists for degree of dysplasia ( $n=10$ low, $L ; n=12$ moderate, $M ; n=10$ high, $H$ ). Histopathologically-confirmed normal colon biopsies $(n=10)$ were used as controls. Complete follow-up data were available for all patients. Among patients with polyps, the median follow-up was 44 months (range 35-96); none developed tumor during this period. At conclusion of the study, 12 (24\%) carcinoma patients had died and $38(76 \%)$ were still alive of whom $22(44 \%)$ remained disease-free, whereas 28 $(56 \%)$ had a recurrence. The median time to recurrence was 10 months (range 1-50). The median follow-up period for survivors was 11 months (range 2-55 months).

Tissue and serum specimens. Aliquots of fresh normal, premalignant and malignant colon tissue were fixed in formalinand paraffin-embedded for immunohistochemical analysis, or placed in liquid nitrogen prior to mRNA extraction. Fresh blood samples from patients and normal subjects were centrifuged at $700 \mathrm{~g}$ for $20 \mathrm{~min}$ at $4^{\circ} \mathrm{C}$. The upper phase (serum) was removed, divided into aliquots and stored at $-20^{\circ} \mathrm{C}$ until use.

RNA extraction and reverse transcription. Frozen sections $(6 \mu \mathrm{m})$ were taken from blocks of tissue and, starting with the first section, every fifth section was routinely stained with hematoxylin and eosin and evaluated histopathologically by an experienced pathologist (Francesco A. Mauri). Sections from areas estimated to have at least $80 \%$ malignant cells were pooled for Endoglin mRNA analysis. Similarly, colon mucosa specimens from patients free of neoplastic or inflammatory diseases were examined by the pathologist and defined as 'normal' tissue. Total RNA was isolated using TRIzol Reagent (Invitrogen, Life Technologies, Gaithersburg, MD) following the manufacturer's instructions, and the RNA concentration was determined by spectrophotometry. Total RNA was treated with DNase I (Invitrogen, Life Technologies) and reversetranscribed using ImProm-II Reverse Transcription System (Promega, Corp., Madison, WI). Briefly, 360 ng of DNase I treated RNA were incubated with $0.5 \mu \mathrm{g}$ of random primer at $70^{\circ} \mathrm{C}$ for $5 \mathrm{~min}$, then added to $15 \mu 1$ of reverse transcription reaction mix containing $1 \mathrm{X}$ ImProm-II reaction buffer, $3 \mathrm{mM}$ $\mathrm{MgCl}_{2}, 0.5 \mathrm{mM}$ dNTPs, $20 \mathrm{U}$ RNasin Ribonuclease Inhibitor and $1 \mu \mathrm{l}$ ImProm-II Reverse Transcriptase and incubated at $42^{\circ} \mathrm{C}$ for $60 \mathrm{~min}$.

Real-time quantitative RT-PCR. Real-time quantitative PCR analysis was performed on iCycler iQ system (Bio-Rad, Hercules, CA) via SYBR Green I dye detection. Complementary DNA (cDNA) corresponding to $5 \mathrm{ng}$ of total RNA was amplified in a reaction ( $25 \mu 1$ total volume) containing 1X iQ SYBR Green Supermix (Bio-Rad) as recommended by the manufacturer. Primers were added to the reaction mix at a final concentration of $300 \mathrm{nM}$. The primer sequences used were as follows: rRNA $18 \mathrm{~S}$, forward primer CTG CCC TAT CAA CTT TCG ATG GTA G, and reverse primer CCG TTT CTC AGG CTC CCT CTC (GenBank accession no. X03205); Endoglin, forward primer GCC AGC ATT GTC TCA CTT CAT G, and reverse primer GCA ACA AGC TCT TTC TTT AGT ACC A (GenBank accession no. AH006911); TGF- $\beta 1$, forward primer GAC ACC AAC TAT TGC TTC AG, and reverse primer CAG GCT CCA AAT GTA GGG (GenBank accession no. X02812); $T G F-\beta$ RII, forward primer AGC ATC ACG GCC ATC TGT G and reverse primer: TGG CAA 
Table I. Main pathological features of the colon carcinoma population studied.

\begin{tabular}{|c|c|c|c|c|c|c|}
\hline Carcinoma Dukes' stages & $\mathrm{A}^{1}$ & $\mathrm{~B} 1^{1}$ & $\mathrm{~B} 2^{2}$ & $\mathrm{C} 1-\mathrm{C} 3^{3}$ & $\mathrm{D}^{4}$ & Total \\
\hline N. & $8(16 \%)$ & $7(14 \%)$ & $13(26 \%)$ & $13(26 \%)$ & $9(18 \%)$ & $50(100 \%)$ \\
\hline \multicolumn{7}{|l|}{ Grading } \\
\hline G1 & 2 & 1 & 0 & 0 & 0 & $3 \quad(6 \%)$ \\
\hline G2 & 5 & 5 & 11 & 9 & 6 & $36(72 \%)$ \\
\hline G3 & 2 & 1 & 1 & 4 & 3 & $11(22 \%)$ \\
\hline \multicolumn{7}{|l|}{ Tumor site } \\
\hline Right colon & 2 & 3 & 5 & 3 & 4 & $17(34 \%)$ \\
\hline Transverse colon & 0 & 0 & 1 & 1 & 0 & $2 \quad(4 \%)$ \\
\hline \multicolumn{7}{|l|}{ Descending and } \\
\hline Sigmoid colon & 3 & 2 & 5 & 5 & 7 & $22(44 \%)$ \\
\hline Rectum & 1 & 2 & 1 & 2 & 3 & $9(18 \%)$ \\
\hline
\end{tabular}

Data are presented as medians (range) for continuous variables, and as frequencies (\%) for categorical variables.

ACC GTC TCC AGA GT (GenBank accession no. M85079). Negative controls omitted cDNA from specific PCR amplification. For each patient the PCR was run in triplicate. Specificity of the amplicons was confirmed from the melting curve of the PCR product at the end of the reaction. PCR efficiency (E) was determined using the iCycler iQ software and the method described by Ramakers et al (32). For each sample the Ct was acquired using the Fit point Method (33). The relative expression ratio of the target cytokine genes was computed using the relative expression software tool (REST) (34): this software calculates an expression ratio relative to the control group (normal tissue) normalized to rRNA $18 \mathrm{~S}$. The expression ratio $(\mathrm{R})$ is: $\mathrm{R}=E_{\text {target }} \Delta \mathrm{Ct}$ target (mean control-mean sample) $/ E_{\text {reference }} \Delta \mathrm{Ct}$ reference (mean control-mean sample).

Immunohistochemical detection of CD105, TGF- $\beta 1$ and $T G F-\beta$ RII. Immunohistochemical analysis was performed on formalin-fixed, paraffin-embedded serial sections. The antiCD105 (SN6h, Dako, Carpinteria, CA, USA) reacting with both forms of Endoglin (the smaller form with $M_{r} 160,000$, termed S-EDG and the larger form with $M_{r} 170,000$, termed L-EDG) (35), anti-TGF-ß1, and -TGF-ß RII monoclonal antibodies (Santa Cruz Biotech., Santa Cruz, CA) were diluted $1: 10,1: 100$, and 1:70, respectively, in phosphate-buffered saline (PBS) in accordance with the manufacturer's recommendations. Briefly, sections were dewaxed and rehydrated through decreasing alcohol series up to distilled water. Endogenous peroxidase activity was suppressed by incubation with $3 \%(\mathrm{v} / \mathrm{v})$ hydrogen peroxide in phosphate-buffered saline (PBS) for $10 \mathrm{~min}$. Heat-induced epitope retrieval was performed with Target Retrieval Solution (Dako) using an electric pressure-cooker for $20 \mathrm{~min}$ at $120^{\circ} \mathrm{C}$, with cooling before immunostaining. Non-specific binding was blocked using $1 \%(\mathrm{v} / \mathrm{v})$ normal horse serum for $30 \mathrm{~min}$, and the slides were then incubated with diluted primary antibodies for $1 \mathrm{~h}$ followed by PBS wash. Antibody binding was localized using a secondary biotin-labeled anti-mouse antibody and the streptavidin-conjugated horseradish peroxidase LSAB-2 kit (Dako), and revealed using 3,3'-diaminobenzidine (DAB) as the chromogenic substrate for peroxidase. The slides were then rinsed with PBS, counterstained with Mayer's hematoxylin and mounted with mounting medium.

All the sections were interpreted by a pathologist (F.A. Mauri) who was blind to clinical findings. Positive and negative controls were included in all reactions. MVD were quantified by the method proposed by Weidner et al (36). Briefly, the sections were scanned at magnification x100 to select the three areas with the most vascularization (hot-spots), in which the microvessels were counted at magnification x200 and their density expressed as the mean number of microvessels $/ \mathrm{mm}^{2}$. Any brown-stained single cell or cell cluster, with or without a discernible lumen, which was clearly separated from the adjacent microvessels, tumor cells or other elements of connective tissue was considered to be a countable vessel. TGF- $\beta 1$ and TGF- $ß$ RII immunostaining was scored by the immunoreactive score (IRS) system proposed by Rammele and Stegner (37) in which IRS = SI (staining intensity) x PP (percentage of positive cells). SI was classified as 0 , negative; 1, weak; 2, moderate; and 3, strong. PP was defined as 0 , negative; $1,1-20 \%$ positive cells; 2, 21-50\% positive cells; and 3, 51-100\% positive cells. Ten visual fields from different areas of each specimen were chosen at random for IRS evaluation, and the average IRS was calculated.

Determination of Endoglin and TGF- $\beta 1$ concentrations in sera. Soluble Endoglin and TGF- $\beta 1$ concentrations were determined in serum samples collected from adenoma and cancer patients and control subjects, using a commercial ELISA kit (R\&D Systems, Abingdon, UK), following the 
manufacturer's instructions. For TGF-ß1 determination, serum samples were tested after transient acidification (reduction of the $\mathrm{pH}$ to 1.5 by addition of $1 \mathrm{~N} \mathrm{HCl}$ for $10 \mathrm{~min}$ at room temperature and neutralization with $1.2 \mathrm{~N} \mathrm{NaOH}$ in $0.5 \mathrm{M}$ HEPES). All samples were evaluated in duplicate. The minimum detectable concentrations of Endoglin ranged from 0.001 to $0.030 \mathrm{ng} / \mathrm{ml}$, for TGF-B1 from 1.7 to $15.4 \mathrm{pg} / \mathrm{ml}$.

Statistical analysis. For statistical analysis the non-parametric Mann-Whitney test was used to compare median values with clinico-pathological variables. The correlation between different parameters was analyzed using the non-parametric Spearman correlation coefficient. Disease-free survival rates were analyzed using Kaplan-Meier curves and the related log-rank test. Calculation of the relative hazard ratios and the relative $95 \%$ confidence intervals using Cox proportional hazard model was employed. Differences were considered significant when $\mathrm{p}<0.05$. All of the statistical analyses were performed using the SPSS for Windows (13.0) package (SPSS, Inc., Chicago, IL).

\section{Results}

Expression of Endoglin, TGF $\beta-1$ and TGF- $\beta$ RII mRNA in normal, dysplastic and malignant colorectal tissues. Endoglin, TGFß-1 and TGF- $\beta$ RII gene expression was quantitatively assessed in normal colon, adenoma at various degrees of dysplasia and adenocarcinoma at different Dukes' stages, using real-time RT-PCR. Normalized gene expression was compared between the different groups, and expression ratios were calculated using the REST software. As shown in Fig. 1, in general Endoglin mRNA was significantly up-regulated in adenoma and tumors versus (vs) control normal mucosa ( $\mathrm{p} \leq 0.001$ and $<0.001$, respectively) and in carcinoma vs adenoma $(\mathrm{p}=0.002)$. Interestingly, when the different degrees of colon polyp dysplasia (mild, moderate, high) were associated with Endoglin expression mRNA ratio, a progressive increase in Endoglin transcript accumulation in adenomatous tissue was observed (Table II). When cancer patients were divided into Dukes' stages A, B, C or D, these different disease stages were not associated with significant variations in Endoglin mRNA expression ( $\mathrm{p}>0.05)$, excepting Dukes' A vs Dukes' B $(\mathrm{p}=0.046)$ (Table II).

$T G F-\beta 1$ mRNA levels in adenoma and tumors were significantly more abundant than in normal colon mucosa $(\mathrm{p}=0.006$ and $<0.001$, respectively) and in carcinoma vs adenoma $(\mathrm{p}<0.001)$ (Fig. 1). There were no significant differences in $T G F-\beta 1$ mRNA levels between the different degrees of colon polyp dysplasia (Table II). By contrast, when cancer patients were categorized on the basis of tumor stage of the Dukes' classification, a progressive increase in $T G F-\beta 1$ transcript accumulation was observed $(\mathrm{p}<0.05)$ (Table II).

$T G F-\beta R I I$ mRNA accumulation was similar in normal, adenoma and carcinoma. Moreover, the different degree of displasia of adenoma and Dukes' staging in carcinoma could not be distinguished on the basis of $T G F-\beta R I I$ transcript (Table II).

Endoglin, TGF- $\beta 1$ and TGF- $\beta$ RII proteins in situ expression in normal, dysplastic and malignant colorectal tissues. Since

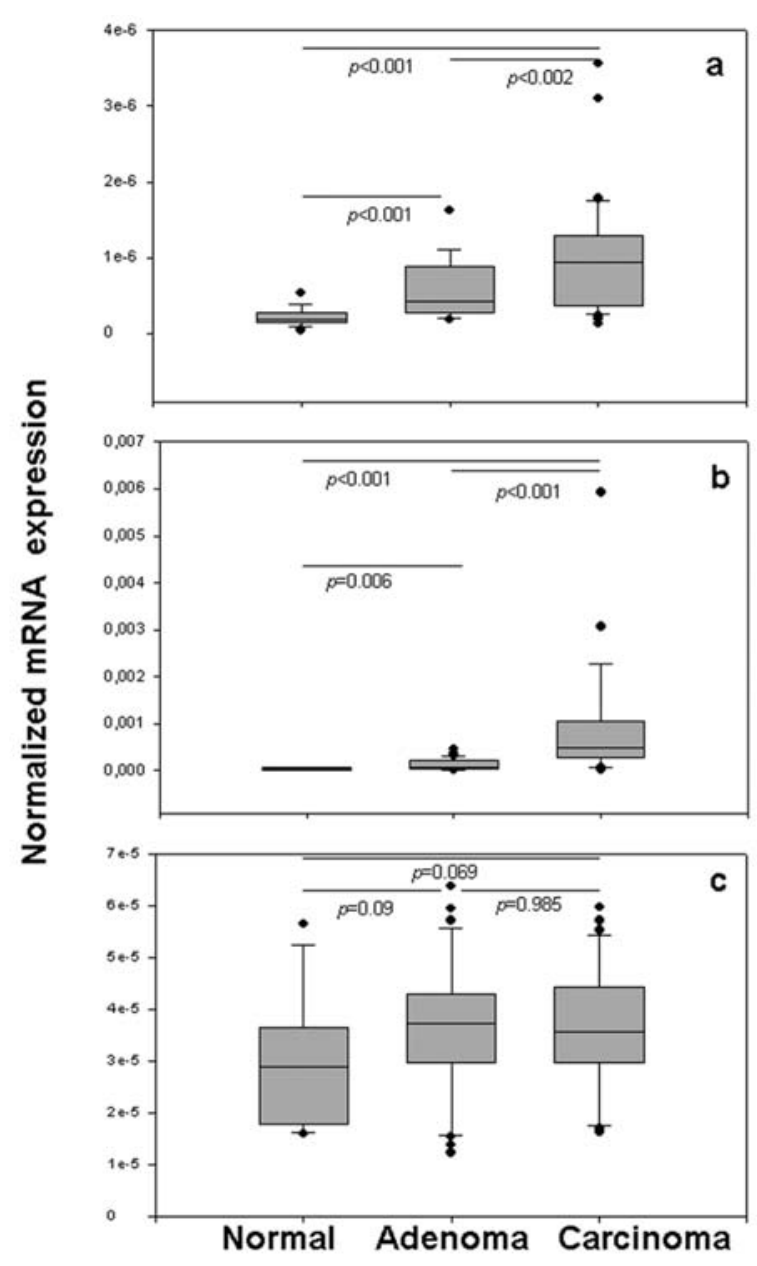

Figure 1. Expression levels of Endoglin, TGF- $\beta 1$ and TGF- $\beta 1$ RII mRNA in normal mucosa, polyps and carcinoma of the colon were assessed via realtime RT-PCR, and normalized to rRNA $18 \mathrm{~S}$ levels. Normalized Endoglin, $T G F-\beta 1$ and $T G F-\beta 1 R I I$ mRNA expression values are presented in (a), (b) and (c), respectively. Median, 10th, 25th, 75th and 90th percentiles are presented as vertical boxes with error bars. Dots indicate outliers. P-values obtained by the Mann-Whitney U test.

mRNA expression does not necessarily correspond to protein expression, and because the presence of varying amounts of normal counterpart in specimens cannot be excluded, we next analyzed adenoma and tumor tissues to establish, by immunohistochemistry, in situ expression status of Endoglin, TGF- $\beta 1$ and TGF- $\beta$ RII in comparison with normal colon mucosa.

Fig. 2 shows representative Endoglin/CD105 differential expression patterns for normal, dysplastic and malignant colorectal tissues. The microvessels in colon mucosa from normal controls were usually minimally positive or totally negative to CD105. In adenoma, CD105 was expressed by $27 \%$ of vascular endothelial cells, preferentially observed in the surface area. In the tumor tissues, CD105 stained positively only in a subset of microvessels (64\%). Preferentially, the anti-CD105 mAb stained endothelial sprouts and small vessels with a restricted lumen. The median (range) CD105+-MVDcalculated for normal, adenoma and carcinoma cases were $0 / \mathrm{mm}^{2}(0-1), 1.8 / \mathrm{mm}^{2}(0-4)$, and $3.8 / \mathrm{mm}^{2}$ (2.12-9.760), respectively. As shown in Fig. 3, a significant increase in CD105+-MVD occurred in the normal-adenoma-carcinoma sequence (normal vs adenoma, $\mathrm{p}=0.001$, normal vs carcinoma, 
Table II. Endoglin, $T G F-\beta 1$ and $T G F-\beta$ RII gene expression ratios in relation to colon adenoma and carcinoma specimens.

\begin{tabular}{|c|c|c|c|}
\hline & \multicolumn{3}{|c|}{$\begin{array}{l}\text { Gene expression ratio } \\
\text { median (range) })^{\mathrm{a}}\end{array}$} \\
\hline & Endoglin & $T G F-\beta 1$ & $T G F-\beta R I I$ \\
\hline Adenoma $(\mathrm{n}=32)$ & $2.010(0.867-7.646)$ & $1.824(0.190-10.170)$ & $1.237(0.409-2119)$ \\
\hline \multirow[t]{3}{*}{ Mild dysplasia $(\mathrm{n}=10)$} & $1.154(0.867-1.252)$ & $1.806(0.590-10.170)$ & $1.243(0.409-3557)$ \\
\hline & $0.003^{\mathrm{b}, \mathrm{c}}$ & 0.531 & 0.489 \\
\hline & $<0.001^{\mathrm{d}}$ & 0.602 & 0.687 \\
\hline \multirow[t]{2}{*}{ Moderate dysplasia $(n=12)$} & $2.011(1.058-2.760)$ & $1.507(0.296-7.800)$ & $1.390(0.933-3.999)$ \\
\hline & $<0.001^{\mathrm{e}}$ & 0.156 & 0.385 \\
\hline Severe dysplasia $(\mathrm{n}=10)$ & $4.392(3.559-7.646)$ & $3.569(0.190-7.128)$ & $2.248(0.461-2.902)$ \\
\hline Carcinoma $(\mathrm{n}=50)$ & $4.392(0.601-16.734)$ & $10.602(0.555-131.600)$ & $1.337(0.537-2.989)$ \\
\hline \multirow[t]{4}{*}{ Dukes' A (n=8) } & $1.644(1.235-7.971)$ & $2.353(0.555-5.797)$ & $1.261(0.744-2.789)$ \\
\hline & $0.654^{\mathrm{f}}$ & $<0.001$ & 0.586 \\
\hline & $0.046^{\mathrm{g}}$ & $<0.001$ & 0.927 \\
\hline & $0.207^{\mathrm{h}}$ & $<0.001$ & 0.913 \\
\hline \multirow[t]{3}{*}{ Dukes' B1/B2 (n=20) } & $4.017(0.601-7.807)$ & 8.437 (5.859-17.666) & $1.783(0.537-2.586)$ \\
\hline & $0.082^{\mathrm{i}}$ & 0.043 & 0.409 \\
\hline & $0.324^{i}$ & 0.001 & 0.579 \\
\hline \multirow[t]{2}{*}{ Dukes' C (n=13) } & $5.151(1.546-16.734)$ & $12.643(7.424-67.576)$ & $1.471(0.590-2.466)$ \\
\hline & $0.449^{\mathrm{k}}$ & 0.016 & 0.943 \\
\hline Dukes' D (n=9) & $5.467(0.850-8.367)$ & $33.875(16.537-131.600)$ & $1.190(0.565-2.989)$ \\
\hline
\end{tabular}

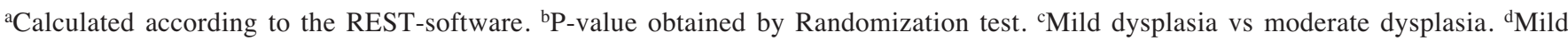
dysplasia vs severe dysplasia. ${ }^{e}$ Moderate dysplasia vs severe dysplasia. ${ }^{\mathrm{f}}$ Dukes' stage A vs Dukes' stage B. ${ }^{\mathrm{g}}$ Dukes' stage A vs Dukes' stage C. h'Dukes' stage A vs Dukes' stage D. 'Dukes' stage B vs Dukes' stage C. 'Dukes' stage B vs Dukes' stage D. 'Dukes' stage C vs Dukes' stage D.

$\mathrm{p}<0.001$, adenoma vs carcinoma, $\mathrm{p}<0.001)$. As shown in Table III, an increment of CD $105^{+}$-MVD from mild-grade dysplasia to high-grade dysplasia was statistically significant. Moreover, CD105+-MVD increased in the process of tumor progression from Dukes' A to Dukes' C.

Representative TGF- 11 differential expression patterns for normal, dysplastic and malignant colorectal tissues are shown in Fig. 2. Moderate or strong immunoreactivities were observed in $81.1 \%$ of cases (27/38) of colorectal cancer, as compared with no positivity or faint staining in $20 \%$ cases of normal colon mucosa. TGF- $\beta 1$ in adenoma and tumor samples was stained more intensely than it was in normal epithelial cells [IRS median (range): 3 (1-4) vs $0.25(0-1)$ and 2(0.5-9) vs $0.25(0-1)$, respectively, $\mathrm{p}<0.001]$. No difference was observed between adenoma and carcinoma $(\mathrm{p}=0.573)$ (Fig. 3). Moreover, as shown in Table III, among the different degrees of adenoma dysplasia only high dysplasia could be distinguished on the basis of TGF- $\beta 1$ staining. By contrast, when tumor samples were analyzed by Dukes' classification, staining intensity with anti-TGF- $\beta 1$ antibody gradually increased in successive stages of colorectal tumor progression. This trend was statistically significant.

Representative TGF-B RII immunostaining patterns for normal, dysplastic and malignant colorectal tissues are shown in Fig. 2. A uniform distribution of TGF-ß RII was found in normal colon epithelial cells as well as in vascular endothelial cells and fibroblasts in the stroma [median (range) IRS: 2 (1-4)]. In general, TGF- $\beta$ RII showed a patchy distribution of staining in adenoma, more intense than in normal tissues [median (range) IRS: $3(0.5-6)$ vs 2 (1-3), $\mathrm{p}=0.031]$. TGF- $\beta$ RII was overexpressed in tumors compared with dysplastic and normal tissues [median (range) IRS: 4 (1-9) vs $3(0.5-6)$ and $2(1-4), p=0.002$ and $\mathrm{p}=0.005$, respectively]. In a few neoplastic samples, a low content of receptor was observed in individual cells within the malignant epithelial clusters $(6 \%)$. The immunoreactivity of the endothelial and stromal compartments was similar in normal, adenoma and tumor tissues (Fig. 3). As shown in Table III the different degrees of adenoma dysplasia and the Dukes stage in colorectal carcinoma could not be distinguished on the basis of TGF- $\beta$ RII expression.

Soluble Endoglin and TGF- $\beta 1$ serum levels in patients with colon adenoma and carcinoma versus healthy donors. Since in certain tumors soluble Endoglin concentrations are increased (38), using specific ELISA we measured soluble Endoglin levels in sera from adenoma and colon carcinoma patients vs normal controls. As shown in Fig. 4a, in general 


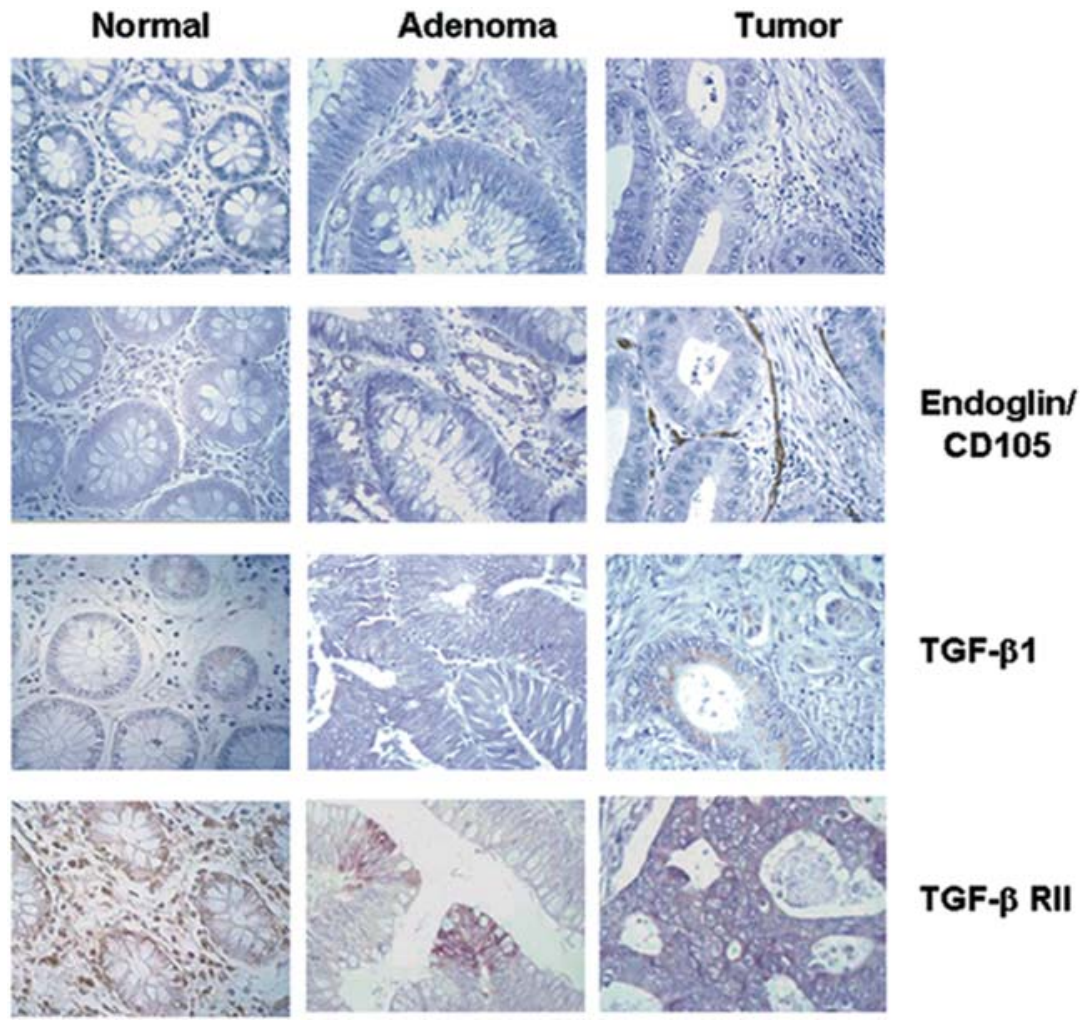

Figure 2. Patterns of typical Endoglin/CD105, TGF-ß1 and TGF-B RII immunostaining in normal, dysplastic and malignant colorectal tissues, using a representative example of a moderate dysplasia adenoma and Dukes' D colon carcinoma (original magnification x250).
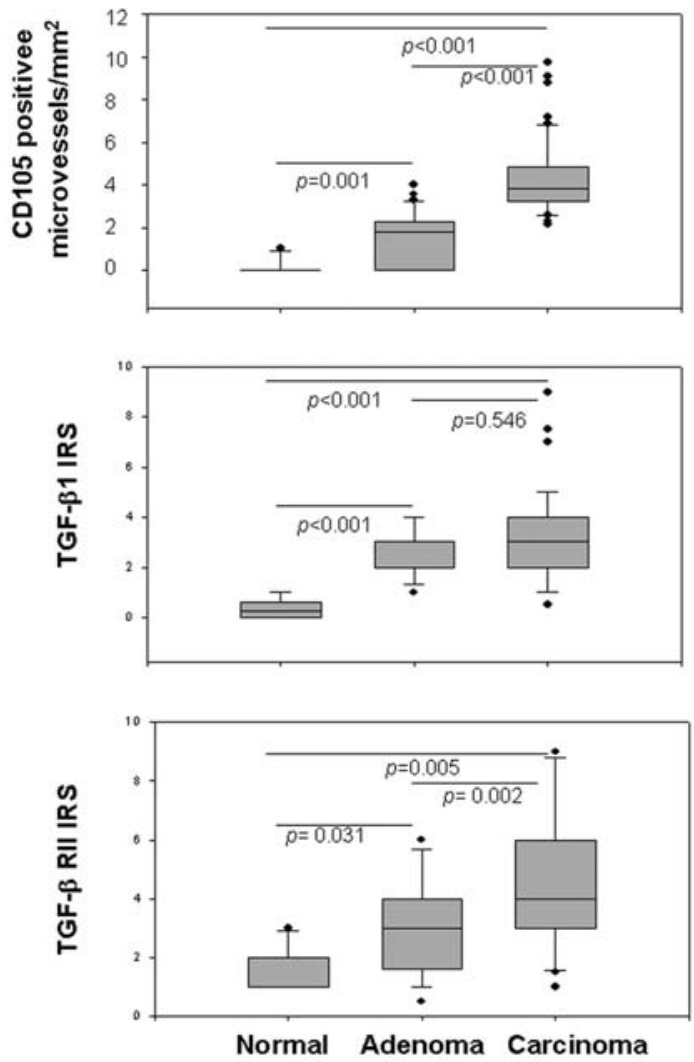

Figure 3. Quantitative analysis of immunohistochemical staining of normal, dysplastic and neoplastic colonic mucosa with anti-CD105, -TGF- 31 , TGF- $\beta$ RII antibodies. The microvessel density (MVD) and immunoreactive scores (IRS) were obtained as described in Materials and methods. Median, 10th, 25th, 75th and 90th percentiles are presented as vertical boxes with error bars. Dots indicate outliers. P-values obtained by the Mann-Whitney U test.

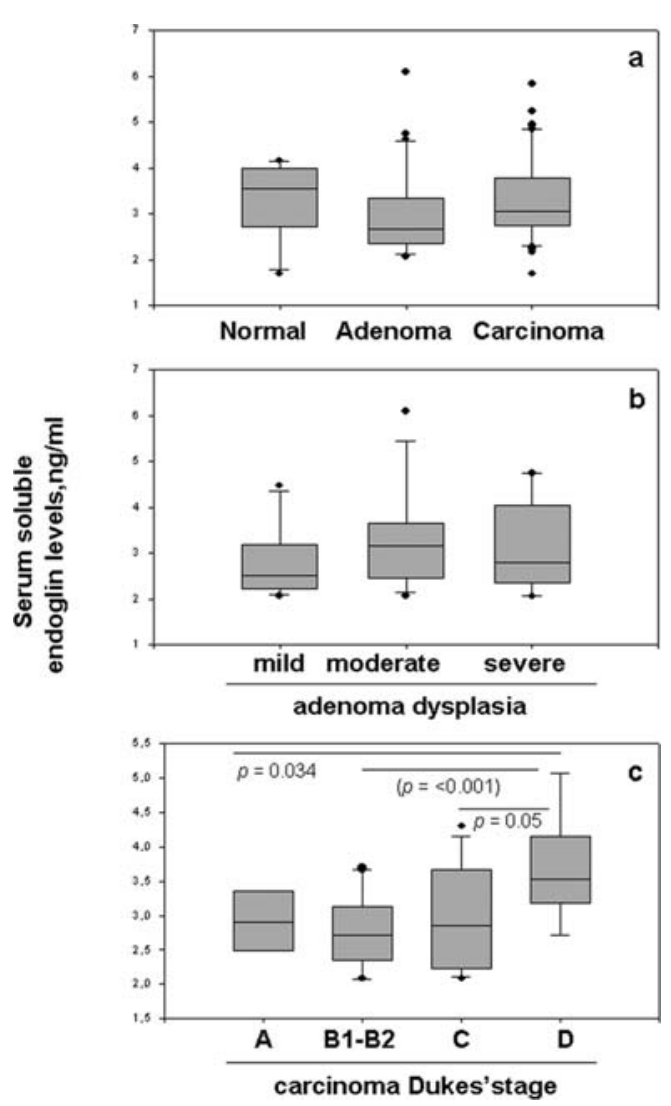

Figure 4. Serum Endoglin concentration by ELISA in normal, adenoma and carcinoma (a), in adenoma patients categorized by degree of dysplasia ( b), and in carcinoma patients categorized by Dukes' stage (c). Median, 10th, 25th, 75th and 90th percentiles are presented as vertical boxes with error bars. Dots indicate outliers. 
Table III. Endoglin, TGF-ß1 and TGF- $ß$ RII protein expression in normal tissue, colon adenoma and carcinoma specimens.

\begin{tabular}{|c|c|c|c|}
\hline & \multicolumn{3}{|c|}{ Immunoreactivity } \\
\hline & $\begin{array}{c}\text { Endoglin } \\
\left(\mathrm{CD} 105^{+}-\mathrm{MVD}\right)^{\mathrm{a}}\end{array}$ & $\begin{array}{l}\text { TGF- } 11 \\
(\text { IRS) }\end{array}$ & $\begin{array}{c}\text { TGF-ß RII } \\
\text { (IRS) }\end{array}$ \\
\hline \multicolumn{4}{|l|}{ Adenoma } \\
\hline \multirow[t]{3}{*}{ Mild dysplasia $(n=10)$} & $0(0-2.3)$ & $2(1-3)$ & $2(0.5-6)$ \\
\hline & $0.009^{c}$ & 0.074 & 0.845 \\
\hline & $0.001^{\mathrm{d}}$ & 0.008 & 0.1 \\
\hline \multirow[t]{2}{*}{ Moderate dysplasia $(n=12)$} & $2(0-3)$ & $3(2-4)$ & $2.75(0.5-6)$ \\
\hline & $0.134^{\mathrm{e}}$ & 0.321 & 0.09 \\
\hline Severe dysplasia $(n=10)$ & $2.2(1-4)$ & $3.5(2-4)$ & $4(2-5)$ \\
\hline \multicolumn{4}{|l|}{ Carcinoma $(n=50)$} \\
\hline \multirow[t]{4}{*}{ Dukes' A $(\mathrm{n}=8)$} & $2.660(2.170-3.670)$ & $1(0.5-2)$ & $3.5(1.5-9)$ \\
\hline & $0.006^{\mathrm{f}}$ & 0.006 & 0.623 \\
\hline & $0.001^{\mathrm{g}}$ & $<0.001$ & 0.882 \\
\hline & $<0.001^{\mathrm{h}}$ & $<0.001$ & 0.633 \\
\hline \multirow[t]{3}{*}{ Dukes' B1/B2 (n=20) } & $3.535(2.120-4.50)$ & $2.5(1-4)$ & $3.5(1-9)$ \\
\hline & $<0.001^{\mathrm{i}}$ & 0.026 & 0.593 \\
\hline & $<0.001^{\mathrm{j}}$ & $<0.001$ & 0.321 \\
\hline \multirow[t]{2}{*}{ Dukes' C (n=13) } & $4.670(3.20-9.09)$ & $3(2-5)$ & $3.5(1-9)$ \\
\hline & $0.125^{\mathrm{k}}$ & 0.025 & 0.472 \\
\hline Dukes' D $(n=9)$ & $5.30(4.230-9.760)$ & $5(3-9)$ & $5(1.5-9)$ \\
\hline
\end{tabular}

${ }^{a}$ MVD calculated as reported in Materials and methods. ${ }^{b}$ IRS calculated as reported in Materials and methods. ${ }^{c}$ Mild dysplasia vs moderate dysplasia. ${ }^{\mathrm{d}}$ Mild dysplasia vs severe dysplasia. ${ }^{\mathrm{e}}$ Moderate dysplasia vs severe dysplasia. ${ }^{\mathrm{f}}$ Dukes' stage A vs Dukes B. ${ }^{\mathrm{g}}$ Dukes' stage A vs Dukes C. 'Dukes' stage A vs Dukes D. 'Dukes' stage B vs Dukes C. 'Dukes' stage B vs Dukes D. 'Dukes' stage C vs Dukes' stage D.

no statistically-significant differences were observed between normal subjects and patients with benign or neoplastic disease [(median (range) values $3.547(1.689-4.165) \mathrm{ng} / \mathrm{ml}$, $2.052(2.530-6.100)$ and $3.059(1.689-5.834) \mathrm{ng} / \mathrm{ml}$, respectively $(\mathrm{p}>0.05)]$. Moreover, although serum Endoglin concentrations were not correlated with the degree of dysplasia (Fig. 4b), all of the highest Endoglin values were detected in serum samples from Dukes' D carcinoma patients (Fig. 4c). Post-operative Endoglin serum measurement, performed approximately one week after surgery in colorectal carcinoma patients, showed no significant difference compared to pre-surgery values [median (range) $3.059(1.689-5.834) \mathrm{ng} / \mathrm{ml}$ vs $3.035(2.080-5.050) \mathrm{ng} / \mathrm{ml}$, $\mathrm{p}=0.266)]$.

As shown in Fig. 5A, serum levels of TGF- 31 in patients with colorectal carcinoma median (range) [40.5 (24-60) pg/ml] were significantly higher than those in the healthy control group [34.7 (18.3-45.6) $\mathrm{pg} / \mathrm{ml}, \mathrm{p}=0.017]$ and than those in adenoma patients [34 (20-45) pg/ml, $<<0.001]$. TGF- 31 serum concentrations were significantly higher in high dysplastic adenoma ( $\mathrm{p}>0.05)$ [high dysplasia: $40.5(32-45) \mathrm{pg} / \mathrm{ml}$ vs low dysplasia: 25.5 (21-41) pg/ml, p=0.001] (Fig. 5B). Serum levels of TGF- $\$ 1$ also increased from Dukes' tumor stages A to $C$ and $D(p<0.01)$ (Fig. 5C). The median serum level of TGF- $\beta 1$ in patients with colorectal carcinoma before surgery dropped significantly, to 34 (22-49) pg/ml, after curative surgical resection of the tumor $(p<0.001)$. Serum levels of TGF- $\beta 1$ after tumor resection decreased more significantly in Dukes' D patients with higher preoperative levels of TGF-ß1, from 53.5 (43-60) $\mathrm{pg} / \mathrm{ml}$ to $36(28-49) \mathrm{pg} / \mathrm{ml}(\mathrm{p}<0.001)$ which was within the normal range.

Correlation between CD105+-MVD, TGF- $\beta 1$ IRS, TGF- $\beta$ RII IRS and circulating Endoglin and TGF- $\beta 1$ levels in patients with colon adenoma and carcinoma. To investigate the relationship between in situ Endoglin, TGF-ß1 and TGF-ß RII expression and circulating Endoglin and TGF- $\beta 1$ levels, we used the Spearman's rank correlation test to correlate the findings obtained by immunohistochemistry and the serum concentrations of the proteins detected by ELISA. In adenoma patients, no significant association was found between any of the variables considered. By contrast, statistically significant positive correlations were found in carcinoma patients: CD105+-MVD vs serum Endoglin levels $(r=0.308, p=0.03$ ), TGF-ß1 IRS vs circulating TGF- $\beta 1$ levels ( $\mathrm{r}=0.567, \mathrm{p}=0.0001)$, TGF- $\beta 1$ IRS vs TGF- $\beta$ RII IRS ( $r=0.281, p=0.04)$, circulating TGF- $\beta 1$ levels vs CD105+-MVD ( $\mathrm{r}=0.623, \mathrm{p}=0.0001)$, TGFB1 IRS vs serum Endoglin levels $(r=0.332, p=0.02)$, and TGF-ß1 IRS vs CD105+-MVD ( $r=0.494, \mathrm{p}=0.0001)$. 


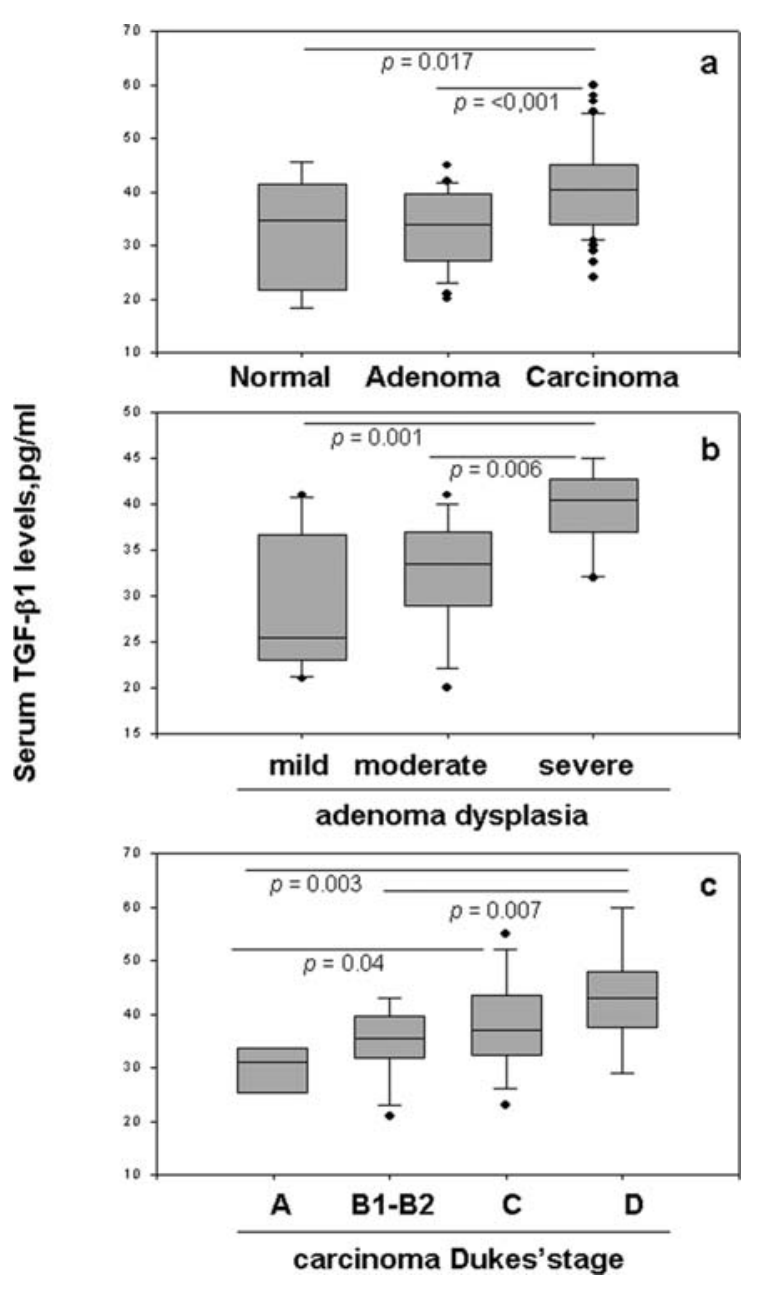

Figure 5. Serum TGF- $\beta 1$ concentration by ELISA in normal, adenoma and carcinoma (a), in adenoma patients categorized by degree of dysplasia (b), and in carcinoma patients categorized by Dukes' stage (c). Median, 10th, 25th, 75th and 90th percentiles are presented as vertical boxes with error bars. Dots indicate outliers.

Association of $C D 105^{+}-M V D, T G F-\beta 1$ IRS, TGF- $\beta$ RII IRS and circulating Endoglin and TGF- $\beta 1$ levels with degree of dysplasia in adenoma, Dukes' stage in carcinoma, and disease-free survival. To clarify the clinical significance of our study, we examined the correlation between the degree of dysplasia in adenoma, the Dukes' stage in carcinoma, and in situ expression and circulating levels of the parameters considered. As shown in Table IV, when Endoglin and its receptor complex components were compared with the degree of dysplasia in adenoma patients $(n=32$, of whom 10 , low dysplasia; 12, moderate dysplasia; 10, high dysplasia), a statistically significant correlation was found between dysplasia degree and TGF- $\beta$ RII and CD105+-MVD ( $p=0.039$, and $\mathrm{p}=0.0001$, respectively). When CD105+-MVD, TGF- 31 IRS, TGF- $\beta$ RII IRS and circulating Endoglin and TGF- $\beta 1$ levels were compared with carcinoma patients' Dukes' stages $(n=50)$ of whom 8 Dukes' A, 20 Dukes' B, 13 Dukes' C, and 9 Dukes' $\mathrm{D}$, a statistically-significant correlation was found between Dukes' stage and circulating TGF- $\beta 1$ and Endoglin levels ( $\mathrm{p}=0.0001$, and $\mathrm{p}=0.005$, respectively) and with $\mathrm{CD} 105^{+}-\mathrm{MVD}$ $(\mathrm{p}=0.0001)$.

Kaplan-Meier curves for disease-free survival in carcinoma patients, using median values of different variables as cutoff point between low and high patient groups, combined with univariate analysis, found no difference in disease-free survival for the two groups in the case of TGF- $\beta$ RII $(p=0.44)$, whereas TGF-ß1 and Endoglin plasma levels, TGF-ß1 IRS and $\mathrm{CD} 105^{+}-\mathrm{MVD}$ were significantly and inversely associated with patient disease-free survival: patients with high TGF- $\beta 1$ $(\geq 40.5 \mathrm{pg} / \mathrm{ml})$ and Endoglin $(\geq 3.05 \mathrm{ng} / \mathrm{ml})$ plasma levels, TGF-ß1 IRS ( $\geq 3)$ and CD105+-MVD $(\geq 3.8)$ had significantly shorter disease-free survival $(\mathrm{p}=0.009,0.02,0.002$, and 0.0002 , respectively) (Fig. 3). Multivariate analysis indicated that only plasma TGF- 11 levels were an independent and significant prognostic factor of disease-free survival $(p=0.005)$, being associated with increased risk of poor prognosis (Cox proportional hazard model $(\mathrm{HR})=1.11,1.03-1.20$; 95\% CI $)$ ).

\section{Discussion}

Most colon adenomas remain benign and asymptomatic lesions. However, a small proportion may evolve to malignancy, and there is evidence indicating that almost all colorectal carcinomas develop from adenomatous polyps (39). The angiogenic switch, the process of developing a high-density

Table IV. Correlation of Endoglin and TGF- $\beta 1$ serum levels, CD105+-MVD and TGF- 31 and TGF- $ß$ RII immunostaining with polyp dysplasia degrees and carcinoma Dukes' stages.

\begin{tabular}{|c|c|c|c|c|}
\hline & \multicolumn{2}{|c|}{ Dysplasia degree } & \multicolumn{2}{|c|}{ Dukes' stage } \\
\hline & $\mathrm{r}^{\mathrm{a}}$ & P-value & $\mathrm{r}^{\mathrm{a}}$ & P-value \\
\hline TGF-ß1 (serum levels, pg/ml) & -0.0837 & 0.647 & 0.751 & 0.0001 \\
\hline TGF-ß1 (IRS) & 0.000 & 0.999 & 0.733 & 0.0001 \\
\hline \multirow[t]{2}{*}{ TGF-ß RII (IRS) } & 0.367 & 0.039 & 0.152 & 0.291 \\
\hline & \multicolumn{2}{|c|}{0.36} & \multicolumn{2}{|c|}{0.36} \\
\hline Endoglin (serum levels, ng/ml) & 0.152 & 0.403 & 0.388 & 0.005 \\
\hline CD105+-MVD & 0.633 & 0.0001 & 0.839 & 0.0001 \\
\hline
\end{tabular}

${ }^{\mathrm{a}} \mathrm{r}$, correlation Spearman's coefficient. 

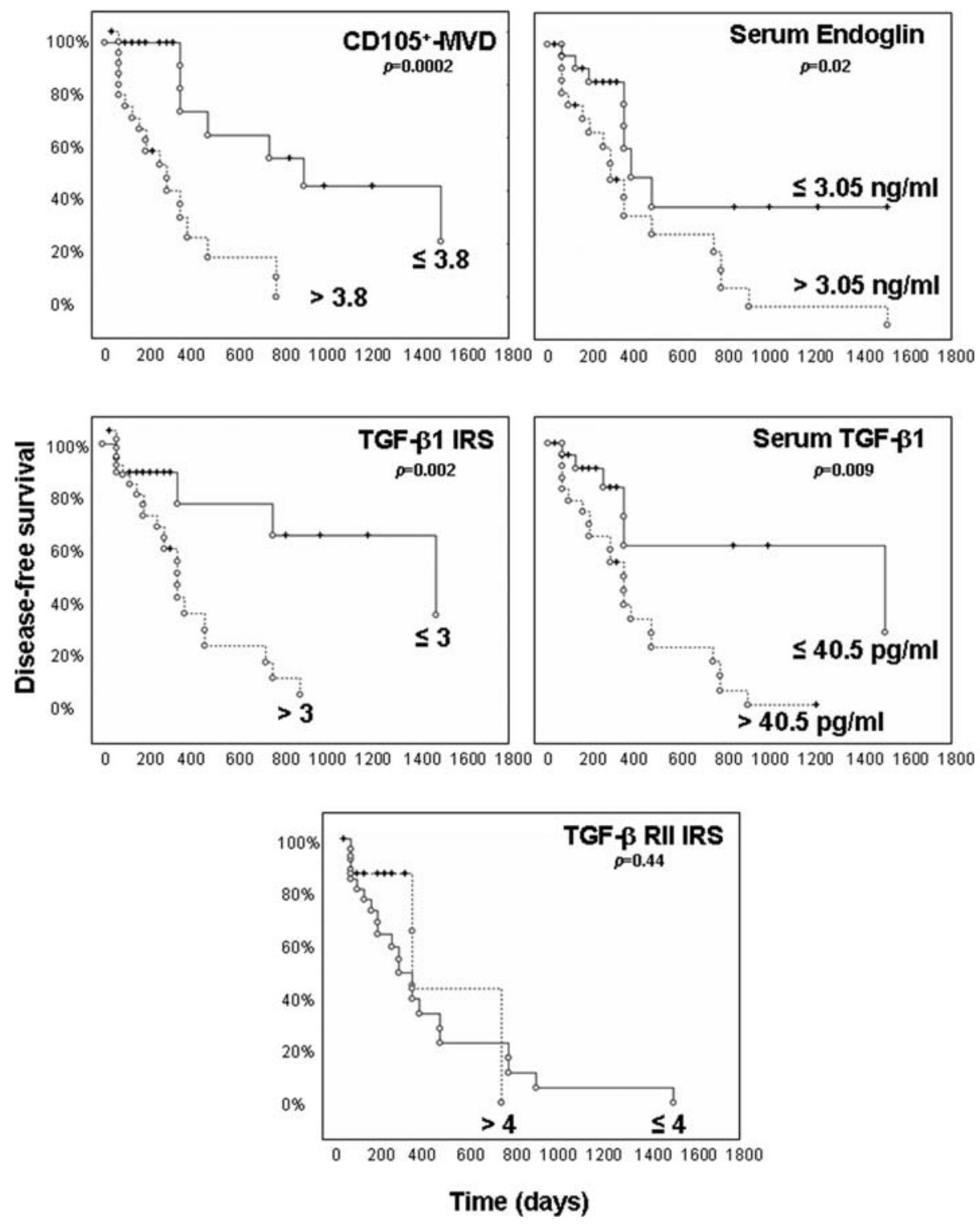

Figure 6. Disease-free survival (analyzed by the Kaplan-Meier method) for patients with high ( $>$ median value) and low ( $\leq$ median value) CD105+microvessel density (MVD), Endoglin and TGF- $ß$ serum levels, TGF- 1 immunoreactive scores (IRS) and TGF- $\beta$ RII IRS. The CD105+-MVD and IRS were obtained as described in the Materials and methods. The significant differences between the two groups are reported (log-rank test).

vascular network that connects tumor and host circulation, is a crucial step for the progression of a tumor from a benign to malignant state (7). Since it was originally believed that the initiation of angiogenesis occurs simultaneously with tumor invasion (40), few studies have investigated angiogenesis at the individual stages of the spectrum from dysplasia to in situ and invasive colon carcinoma $(41,42)$. In this study, we evaluated for the first time the simultaneous expression of the Endoglin/TGF- $\beta$ RII functional complex and its ligands TGF- $\$ 1$ in the colon adenoma-carcinoma sequence, together with its clinical significance. Our data suggest that angiogenesis is initiated early in this sequence, although the greatest increase occurs with tumor invasion. Endoglin, the most reliable marker of proliferating endothelial cells (43), is weakly expressed in normal colon tissue but up-regulated, at both mRNA and protein levels, in adenoma. A progressive increase in Endoglin transcript accumulation and CD $105^{+}-$MVD occurred in adenomatous tissue, from mild to severe dysplasia. These data suggest that tumor angiogenesis is not necessarily a characteristic of invasive tumor, as originally thought, but may be an early event during colon cancer development. Since the expression of CD105 significantly differed from low-grade to high-grade adenoma and to carcinoma whereas, as has been reported, the MVD for a pan-endothelial markers (CD34, CD31) does not (42), it is possible that the very early stages of dysplastic transformation already acquire their vasculature, not only by incorporation of pre-existing normal vessels (recognized by pan-endothelial markers), but also by induction of new blood vessels (recognized by CD105); this ability is characteristic of tumor behavior. Based on experimental evidence, it has been demonstrated that angiogenesis precedes overt tumor formation during chemically-induced carcinogenesis, suggesting that tumor progression depends on a switch from a prevascular to a vascular phase (43). Furthermore, 
MVD has been found significantly increased in a relatively large spectrum of pre-malignant lesions, including oral mucosa (44), bronchial epithelium (45), skin (46), colon dysplasia (41), Barrett's epithelium (47), and the uterine cervix (9).

Our study also shows that accumulation of mRNA for Endoglin is upregulated in colon carcinoma tissues, in comparison with normal and dysplastic colon mucosa. As expected, we found overexpression of Endoglin protein in the endothelium of colon carcinoma tissue, positively correlated with disease progression. These results are in agreement with studies showing that the CD105+-MVD value is a prognostic marker in colon carcinoma $(41,48-50)$, as well as in prostate $(51)$, breast $(52,53)$, kidney $(54)$, esophageal $(55,56)$, head and neck $(57,58)$, uterus $(59)$ and non-small cell lung cancers (60).

Endoglin is not only expressed on the cell surface, but can also be released after proteolytic shedding of the membraneassociated extracellular domain, and may be detected in the blood (62). Quantification of circulating Endoglin levels revealed, for the first time, no significant difference between patients with colon adenoma and normal subjects. Moreover, soluble Endoglin levels were not correlated with the degree of dysplasia. We also found that, in general, serum Endoglin levels in colon carcinoma patients did not differ from those of healthy controls and patients with adenoma. However, all of the highest Endoglin values were detected in serum samples from advanced, metastatic carcinoma patients. This is in line with findings relating to colon carcinoma $(48,62,63)$, breast cancer, and other solid tumor patients $(62,64)$. Therefore, circulating Endoglin levels may be useful as an indicator for disease progression and to identify patients at risk of recurrence and metastasis. The preferential expression of Endoglin in endothelial cells of the tumor vasculature versus neoplastic cells has led to the suggestion that soluble Endoglin originates from the neovasculature (65). Thus, as reported for several severe vascular diseases (66), also in the cancerogenic process soluble Endoglin may prevent binding of TGF-B1 to its signaling receptors, impairing downstream signaling activity. In vitro studies have demonstrated the importance of regulating the availability of active TGF- $\beta$. Low extracellular TGF- $ß 1$ concentrations promote the cell proliferation and migration that is associated with the active proliferation of new vessels in angiogenesis (28). By contrast, high levels of extracellular TGF- $ß 1$ lead to cytostasis and synthesis of ECM proteins that are associated with mature or differentiating vessels (67).

The lack of a significant difference between pre- and post-operative Endoglin serum levels may be explained by the fact that lowered soluble CD105 levels following removal of the tumor are overshadowed by postoperative angiogenesis during the process of wound healing.

Membrane associated Endoglin can bind TGF-B1 with high affinity and regulates its access to the signaling type I and type II receptors (68). Of the three mammalian TGF- $\beta$ isoforms, TGF- $\beta 1$, localized to endothelial cells during embryogenesis (69), is the most likely to be involved in angiogenesis. Our results demonstrate that colon adenoma and cancer cells express higher levels of TGF- $\beta 1$ mRNA and protein than their normal counterparts. Moreover, whereas
TGF-ß1 in situ expression was significantly higher only in high dysplastic polyps, a progressive increase in TGF- 31 transcript and protein accumulation was observed in successive stages of the colorectal tumor progression. TGF- $\beta 1$ has been found to be overexpressed locally in various types of solid tumors, including cancer of the breast $(70)$, colon $(71,72)$, esophagus (73), stomach (74), pancreas (75), liver (76), lung (77), prostate (78), brain (79), and malignant melanoma (80). Overexpression is frequently correlated with advanced tumor stage, metastases and a poorer overall prognosis. In addition, circulating TGF- 31 levels of patients with high dysplastic adenoma were significantly higher in comparison with those of patients with low dysplasia, whereas in carcinoma patients TGF- $\$ 1$ levels progressively increased with disease progression. It has been shown that malignant tumors can not only activate latent TGF- $\beta$ derived from other sources in the microenvironment, but also produce TGF- $\beta 1$ itself (81). Consistent with the idea that tumor-derived TGF- $\beta 1$ is released into the circulation, post-operative serum levels of TGF- $\beta 1$ decreased significantly.

TGF- $\beta$ has been found to have bidirectional functions in the progression of solid cancers: in the early stages it acts as a tumor suppressor by inhibiting epithelial cell proliferation, while in later stages it functions as a pro-oncogenic factor through stimulation of matrix deposition, perturbation of immune function, activation of angiogenesis and induction of EMT (82). The mechanisms whereby TGF- $ß$ switches from being a tumor suppressor to a promoter facilitating tumorigenesis are not fully understood. The effects of the TGF- 31 protein are exerted through specific receptor complexes present on the cell surface: its binding to the type II receptor activates and transphosphorylates the type I receptor, which subsequently propagates the signal by phosphorylating the receptor-regulated Smad (R-Smad) family of proteins that, upon activation, form heteromeric complexes with a cooperative homologue named Co-Smad, that translocate into the nucleus where regulate the transcriptional activity of target genes (21).

Our results show that the TGF- $\beta$ RII protein, present in epithelial cells but also in mesenchymal cells such as fibroblasts and endothelial cells, is overexpressed in adenoma and carcinoma versus the normal colon. However, the different degrees of adenoma dysplasia and Dukes stages in colorectal carcinoma could not be distinguished on the basis of TGF- $\beta$ RII expression. Membrane trafficking defects of RII have been proposed as one mechanism accounting for the loss of growth inhibition by TGF-ß. However, our results provide no argument in favor of reduced or undetectable amounts of cell-surface TGF-ß RII, as observed in a majority of colon cancer cases showing microsatellite instability (83), since the antibody used for detection is directed against the intracellular portion of the receptor. Moreover, the TGF- $\beta$ pathway could still be impaired through mutation of RII, as reported, or through post-receptor event alterations (84).

The functional interaction between TGF-ß1/CD105 should be taken into consideration. In adenoma patients no significant association was found between any of the variables considered. By contrast, a statistically-significant positive cross-relationship was found between local and circulating levels of Endoglin and TGF- $\beta 1$ in carcinoma patients. Studies conducted in 
experimental models provide direct evidence that highly expressed CD105 antagonizes the inhibitory effects of TGF- $\beta 1$ and thus contributes to the proliferation, migration, and capillary formation of endothelial cells, the three key events in the angiogenic process (85). On the other hand, interestingly, TGF- 3 potently stimulates Endoglin expression via Smads (68) and in synergy with the hypoxia pathway (86). Therefore, the progressive loss of TGF- $\beta$ growth inhibition and increased expression of TGF- $\beta$ with the concomitant induction of Endoglin could be the crucial event associated with malignant conversion and progression in colon cancer. However, it cannot be ruled out that, as reported, Endoglin/CD105 can also act independently of the TGF- 3 signaling pathway (68).

To clarify the clinical significance of our study, we examined the correlation between the degree of dysplasia of adenomas, the Dukes' stage of carcinomas, and in situ expression and circulating levels of the parameters considered. A statistically-significant correlation was found between dysplasia degree and TGF- $\beta$ RII and CD105+-MVD. By contrast, a statistically-significant correlation was observed between Dukes' classification and circulating TGF- 11 and Endoglin levels as well as CD105+-MVD.

TGF- $\beta 1$ and Endoglin plasma levels, TGF- $\beta 1$ IRS and MVD were significantly and inversely associated with patient disease-free survival. Multivariate analysis indicated that only plasma TGF- $\beta 1$ levels were an independent and significant prognostic factor of disease-free survival, associated with increased risk of poor prognosis. Both TGF- $\beta 1$ and Endoglin act as valuable indicators of prognosis in several tumors $(56,70,87-97)$.

Currently, as alternative or complementary strategies to traditional chemotherapy, drugs targeting angiogenesis have been developed to block tumor growth and metastases by interrupting, at different levels, the signaling pathways of angiogenic factors. Some of these novel approaches have already been approved by health authorities and are now integrated into cancer care, including that of colon carcinoma (98).

Adenomatous polyps are well-demarcated masses of epithelial dysplasia, with uncontrolled crypt cell proliferation. Some seem to be reversible, but others progress to carcinoma in situ and to invasive carcinoma. Predictive factors of reversibility or progression are virtually unknown. The increased expression of angiogenesis markers Endoglin, TGF- $\beta$ RII and TGF- $\beta 1$ appears to be an early event in the adenoma-carcinoma sequence, in accordance with previous reports showing a close association between proangiogenic VEGF and tissue factor (TF) in the early stages of colorectal development (14). We assume that overexpression of this receptors/ligand complex may participate in colorectal carcinogenesis and may possibly possess prognostic value. It is thought that angiogenesis-targeted chemoprevention may prevent or delay the progression from pre-malignant condition to carcinoma. Thus anti-angiogenic therapy may become an interesting strategy not only in patients with carcinoma, but also in chemoprevention in patients with high risk of developing such a tumor, otherwise submitted to the 'watchful waiting' strategy. However, further studies are necessary to clarify the molecular mechanisms that regulate angiogenesis in pre-malignant conditions in order to provide evidence that support the clinical application of anti-angiogenic drugs in these patients. In this context, preclinical and correlative studies should continue to explore the mechanisms of action as well as predictive markers for efficacy and toxicity.

\section{Acknowledgements}

This work was supported by grants from the Piedmontese Regional Government to G.B.

\section{References}

1. Jemal A, Siegel R, Ward E, Hao Y, Xu J and Thun MJ: Cancer Statistics. CA Cancer J Clin 56: 106-130, 2006.

2. Fearon ER and Vogelstein B: A genetic model for colorectal tumorigenesis. Cell 61: 759-767, 1990.

3. Cho KR and Vogelstein B: Genetic alterations in the adenomacarcinoma sequence. Cancer 70: 1727-1731, 1992.

4. Salgado R, Benoy I, Vermeulen P, van Dam P, van Marck E and Dirix L: Circulating basic fibroblast growth factor is partly derived from the tumour in patients with colon, cervical and ovarian cancer. Angiogenesis 7: 29-32, 2004.

5. Kos M and Dabrowski A: Tumour's angiogenesis - the function of VEGF and bFGF in colorectal cancer. Ann Univ Mariae Curie Sklodowska Med 57: 556-561, 2002.

6. Pardali E and ten Dijke P: Transforming growth factor-beta signaling and tumor angiogenesis. Front Biosci 14: 4848-4861, 2009.

7. Folkman J, Watson K, Ingber D and Hanahan D: Induction of angiogenesis during the transition from hyperplasia to neoplasia. Nature 339: 58-61, 1989 .

8. Barnhill RL, Fandrey K, Levy MA, Mihm MCn Jr and Hyman B: Angiogenesis and tumor progression of melanoma. Quantification of vascularity in melanocytic nevi and cutaneous malignant melanoma. Lab Invest 67: 331-337, 1992.

9. Smith-McCune KK and Weidner N: Demonstration and characterization of the angiogenic properties of cervical dysplasia. Cancer Res 54: 800-804, 1994.

10. Bossi P, Viale G, Lee AK, Alfano R, Coggi G and Bosari S: Angiogenesis in colorectal tumors: microvessel quantitation in adenomas and carcinomas with clinicopathological correlations. Cancer Res 55: 5049-5053, 1995.

11. Fontanini G, Calcinai A, Boldrini L, et al: Modulation of neoangiogenesis in bronchial preneoplastic lesions. Oncol Rep 6: 813-817, 1999.

12. Kitadai Y, Onogawa S, Kuwai T, et al: Angiogenic switch occurs during the precancerous stage of human esophageal squamous cell carcinoma. Oncol Rep 11: 315-319, 2004.

13. Bamberger ES and Perrett CW: Angiogenesis in benign, premalignant and malignant vulvar lesions. Anticancer Res 22: 3853-3865, 2002.

14. Staton CA, Chetwood AS, Cameron IC, Cross SS, Brown NJ and Reed MW: The angiogenic switch occurs at the adenoma stage of the adenoma carcinoma sequence in colorectal cancer. Gut 56: 1426-1432, 2007.

15. Elliott RL and Blobe GC: Role of transforming growth factor beta in human cancer. J Clin Oncol 23: 2078-2093, 2005.

16. Massagué J: TGFbeta in cancer. Cell 134: 215-230, 2008.

17. Yamamoto T, Kozawa O, Tanabe K, Akamatsu S, Matsuno H, Dohi $\mathrm{S}$ and Uematsu T: Involvement of p38 MAP kinase in TGF- 3 -stimulated VEGF synthesis in aortic smooth muscle cells. J Cell Biochem 82: 591-598, 2001.

18. Goumans MJ and Mummery C: Functional analysis of the TGF receptor/Smad pathway through gene ablation in mice. Int $\mathrm{J}$ Dev Biol 44: 253-265, 2000 .

19. Jakowlew SB: Transforming growth factor-beta in cancer and metastasis. Cancer Metastasis Rev 25: 435-457, 2006.

20. Massagué J: TGF-ß signal transduction. Annu Rev Biochem 67: 753-791, 1998

21. Massagué $\mathrm{J}$ and Gomis RR: The logic of TGFß signalling. FEBS Lett 580: 2811-2820, 2006.

22. Shi Y and Massagué J: Mechanisms of TGF- $\beta$ signaling from cell membrane to the nucleus. Cell 13: 685-700, 2003.

23. Barbara NP, Wrana JL and Letarte M: Endoglin is an accessory protein that interacts with the signaling receptor complex of multiple members of the transforming growth factor-beta superfamily. J Biol Chem 274: 584-594, 1999. 
24. Yamashita H, Ichijo H, Grimsby S, Moren A, ten Dijke P and Miyazono K: Endoglin forms a heteromeric complex with the signaling receptors for transforming growth factor-beta. J Biol Chem 269: 1995-2001, 1994.

25. Guerrero-Esteo M, Sanchez-Elsner T, Letamendia A and Bernabeu C: Extracellular and cytoplasmic domains of endoglin interact with the transforming growth factor-beta receptors I and II. J Biol Chem 277: 29197-29209, 2002.

26. Cheifetz S, Bellon T, Cales C, Vera S, Bernabeu C, Massagué J and Letarte $\mathrm{M}$ : Endoglin is a component of the transforming growth factor- $\beta$ receptor system in human endothelial cells. J Biol Chem 267: 19027-19030, 1992.

27. Miller DW, GraulichW, Karges B, et al: Elevated expression of endoglin, a component of the TGF-beta-receptor complex, correlates with proliferation of tumor endothelial cells. Int $\mathrm{J}$ Cancer 81: 568-572, 1999.

28. Lebrin F, Goumans MJ and Jonker L: Endoglin promotes endothelial cell proliferation and TGF-beta/ALK1 signal transduction. EMBO J 23: 4018-4028, 2004.

29. Burrows FJ, Derbyshire EJ, Tazzari PL, et al: Up-regulation of endoglin on vascular endothelial cells in human solid tumors: implications for diagnosis and therapy. Clin Cancer Res 1: 1623-1634, 1995.

30. Dallas NA, Samuel S, Xia L, Fan F, Gray MJ, Lim SJ and Ellis LM: Endoglin (CD105): a marker of tumor vasculature and potential target for therapy. Clin Cancer Res 14: 1931-1937, 2008.

31. Astler VB and Coller FA: The prognostic significance of direc extension of carcinoma of the colon and rectum. Ann Surg 139: 846-852, 1954

32. Ramakers C, Ruijter JM, Deprez RH and Moorman AF: Assumption-free analysis of quantitative real-time polymerase chain reaction (PCR) data. Neurosci Lett 339: 62-66, 2003

33. Rasmussen R: Quantification on the LightCycler. In: Rapid Cycle Real-time PCR, Methods and Applications. Meuer S, Wittwer C and Nakagawara K (eds.) Springer Press, Heidelberg, pp21-34, 2001.

34. Pfaffl MW, Horgan GW and Dempfle L: Relative expression software tool (REST) for group-wise comparison and statistical analysis of relative expression results in real-time PCR. Nucleic Acids Res 30: e36, 2002.

35. Haruta Y and Seon BK: Distinct human leukemia-associated cell surface glycoprotein GP160 defined by monoclonal antibody SN6. Proc Natl Acad Sci USA 83: 7898-7902, 1986.

36. Weidner N, Semple JP, Welch WR and Folkman J: Tumor angiogenesis and metastasis correlation in invasive breast carcinoma. N Engl J Med 324: 1-8, 1991.

37. Remmele W and Stegner HE: Recommendation for uniform definition of an immunoreactive score (IRS) for immunohistochemical estrogen receptor detection (ER-ICA) in breast cancer tissue. Pathologe 8: 138-140, 1987.

38. Nakagawa S and Kitoh T: Measurement of KIT ligand/stem cell factor: clinical and biochemical significance. Curr Opin Hematol 7: 133-142, 2000.

39. Konishi F and Morson BC: Pathology of colorectal adenomas: a colonoscopic survey. Clin Pathol 35: 830-841, 1982.

40. Bergers $\mathrm{G}$ and Benjamin LE: Tumorigenesis and the angiogenic switch. Nat Rev Cancer 3: 401-410, 2003

41. Akagi K, Ikeda Y, Sumiyoshi Y, Kimura Y, Kinoshita J, Miyazaki $M$ and Abe T: Estimation of angiogenesis with antiCD105 immunostaining in the process of colorectal cancer development. Surgery 31: S109-S113, 2002

42. Minhajat R, Mori D, Yamasaki F, Sugita Y, Satoh T and Tokunaga O: Endoglin (CD105) expression in angiogenesis of colon cancer: analysis using tissue microarrays and comparison with other endothelial markers. Virchows Arch 448: 127-134, 2006.

43. Hanahan D and Folkman J: Patterns of emerging mechanisms of the angiogenic switch during tumorigenesis. Cell 86: 353-364, 1996.

44. Jin Y, Tipoe GL, White FH and Yang L: A quantitative investigation of immunocytochemically stained blood vessels in normal, benign, premalignant and malignant human oral cheek epithelium. Virchows Arch 427: 145-151, 1995.

45. Meert A-P, Feoli F, Martin B, Ninane V and Sculier J-P: Angiogenesis in preinvasive, early invasive bronchial lesions and micropapillomatosis and correlation with EGFR expression. Histopathology 50: 311-317, 2007.

46. Van der Kerkhof PC, Rulo HF, van Pelt JP, van VlijmenWillems IM and De Jong EM: Expression of endoglin in the transition between psoriatic uninvolved and involved skin. Acta Derm Venereol 78: 19-21, 1998.
47. Auvinen MI, Sihvo EI, Ruohtula T, et al: Incipient angiogenesis in Barrett's epithelium and lymphangiogenesis in Barrett's adenocarcinoma. J Clin Oncol 20: 2971-2979, 2002.

48. Li C, Gardy R, Seon BK, et al: Both high intratumoral microvessel density determined using CD105 antibody and elevated plasma levels of CD105 in colorectal cancer patients correlate with poor prognosis. Br J Cancer 88: 1424-1431, 2003.

49. Saad RS, Liu YL, Nathan G, Celebrezze J, Medich D and Silverman JF: Endoglin (CD105) and vascular endothelial growth factor as prognostic markers in colorectal cancer. Mod Pathol 17: 197-203, 2004.

50. Romani AA, Borghetti AF, Del Rio P, Sianesi M and Soliani P: The risk of developing metastatic disease in colorectal cancer is related to CD105-positive vessel count. J Surg Oncol 93: 446-455, 2006

51. Wikström P, Lissbrant IF, Stattin P, Egevad L and Bergh A: Endoglin (CD105) is expressed on immature blood vessels and is a marker for survival in prostate cancer. Prostate 51: 268-275, 2002.

52. Bodey B, Bodey B, Siegel SE and Kaiser HE: Overexpression of endoglin (CD105): a marker of breast carcinoma-induced neo-vascularization. Anticancer Res 18: 3621-3628, 1998.

53. Kumar S, Ghellal A, Li C, Byrne G, Haboubi N, Wang JM and Bundred N: Breast carcinoma: vascular density determined using CD105 antibody correlates with tumor prognosis. Cancer Res 59: 856-861, 1999

54. Sandlund J, Hedberg Y, Bergh A, Grankvist K, Ljungberg B and Rasmuson T: Endoglin (CD105) expression in human renal cell carcinoma. BJU Int 97: 706-710, 2006.

55. Saad RS, El-Gohary Y, Memari E, Liu YL and Silverman JF: Endoglin (CD105) and vascular endothelial growth factor as prognostic markers in esophageal adenocarcinoma. Hum Pathol 36: 955-961, 2005

56. Bellone G, Solerio D, Chiusa L, et al: Transforming growth factor-beta binding receptor endoglin (CD105) expression in esophageal cancer and in adjacent non-tumorous esophagus as prognostic predictor of recurrence. Ann Surg Oncol 14: 3232-3242, 2007

57. Kyzas PA, Agnantis NJ and Stefanou D: Endoglin (CD105) as a prognostic factor in head and neck squamous cell carcinoma. Virchows Arch 448: 768-775, 2006.

58. Martone $\mathrm{T}$, Rosso $\mathrm{P}$, Albera R, et al: Prognostic relevance of $\mathrm{CD}_{105^{+}}$microvessel density in HNSCC patient outcome. Oral Oncol 41: 147-155, 2005.

59. Saad RS, Jasnosz KM, Tung MY and Silverman JF: Endoglin (CD105) expression in endometrial carcinoma. Int J Gynecol Pathol 22: 248-253, 2003

60. Tanaka F, Otake Y and Yanagihara K: Evaluation of angiogenesis in non-small cell lung cancer: comparison between antiCD34 antibody and anti-CD105 antibody. Clin Cancer Res 7: 3410-3415, 2001

61. Bellón T, Corbí A, Lastres P, et al: Identification and expression of two forms of the human transforming growth factor-betabinding protein endoglin with distinct cytoplasmic regions. Eur J Immunol 23: 2340-2345, 1993.

62. Takahashi N, Kawanishi-Tabata R, Haba A, Tabata M, Haruta Y, Tsai H and Seon BK: Association of serum endoglin with metastasis in patients with colorectal, breast, and other solid tumors, and suppressive effect of chemotherapy on the serum endoglin. Clin Cancer Res 7: 524-532, 2001.

63. Mysliwiec P, Pawlak K, Kukliñski A and Kedra B: Combined perioperative plasma endoglin and VEGF-A assessment in colorectal cancer patients. Folia Histochem Cytobiol 47: 231-236, 2009.

64. Li C, Guo B, Wilson PB, Stewart A, Byrne G, Bundred N and Kumar S: Plasma levels of soluble CD105 correlate with metastasis in patients with breast cancer. Int J Cancer 89: 122-126, 2000.

65. Fonsatti E, Altomonte M, Nicotra MR, Natali PG and Maio M: Endoglin (CD105): a powerful therapeutic target on tumorassociated angiogenetic blood vessels. Oncogene 22: 6557-6563, 2003.

66. ten Dijke P, Goumans MJ and Pardali E: Endoglin in angiogenesis and vascular diseases. Angiogenesis 11: 79-89, 2008.

67. Ruiz-Ortega M, Rodriguez-Vita J, Sanchez-Lopez E, Carvajal G and Egido J: TGF- $\beta$ signaling in vascular fibrosis. Cardiovasc Res 74: 196-206, 2007.

68. Bernabeu C, Lopez-Novoa JM and Quintanilla M: The emerging role of TGF-beta superfamily coreceptors in cancer. Biochim Biophys Acta 1792: 954-973, 2009. 
69. Akhurst RJ, Lehnert SA, Faissner A and Duffie E: TGFß in murine morphogenetic processes: the early embryo and cardiogenesis. Development 108: 645-656, 1990.

70. Desruisseau S, Palmari J, Giusti C, Romain S, Martin PM and Berthois Y: Determination of TGFbeta1 protein level in human primary breast cancers and its relationship with survival. $\mathrm{Br}$ Cancer 94: 239-246, 2006.

71. Langenskiöld M, Holmdahl L, Falk P, Angenete E and Ivarsson ML: Increased TGF-beta 1 protein expression in patients with advanced colorectal cancer. J Surg Oncol 97: 409-415, 2008.

72. Bellone G, Carbone A, Tibaudi D, et al: Differential expression of transforming growth factors-beta1, -beta2 and -beta3 in human colon carcinoma. Eur J Cancer 37: 224-233, 2001.

73. Von Rahden BH, Stein HJ, Feith M, Pühringer F, Theisen J, Siewert JR and Sarbia M: Overexpression of TGF-beta1 in esophageal (Barrett's) adenocarcinoma is associated with advanced stage of disease and poor prognosis. Mol Carcinog 45: 786-794, 2006.

74. Suda A, Saito N, Seshimo A, Kameoka S and Kobayashi M: Examination of transforming growth factor betal expression in the serum and tumor tissue of gastric cancer. Int Surg 94: $182-188,2009$

75. Nio Y, Omori H, Hashimoto K, et al: Immunohistochemical expression of receptor-tyrosine kinase c-kit protein and TGF-betal in invasive ductal carcinoma of the pancreas. Anticancer Res 25: 3523-3529, 2005.

76. Dong ZZ, Yao DF, Yao M, et al: Clinical impact of plasma TGF-beta1 and circulating TGF-beta1 mRNA in diagnosis of hepatocellular carcinoma. Hepatobiliary Pancreat Dis Int 7: 288-295, 2008

77. Kong F, Jirtle RL, Huang DH, Clough RW and Anscher MS: Plasma TGF- 31 level before radiotherapy correlates with longterm outcome of patients with lung carcinoma. Cancer 86: 1712-1719, 1999.

78. Cardillo MR, Petrangeli E, Perracchio L, Salvatori L, Ravenna L and Di Silverio F: Transforming growth factor-beta expression in prostate neoplasia. Anal Quant Cytol Histol 22: 1-10, 2000.

79. Bruna A, Darken RS, Rojo F, et al: High TGF- $\beta-S m a d$ activity confers poor prognosis in glioma patients and promotes cell proliferation depending on the methylation of the PDGF-B gene. Cancer Cell 11: 147-160, 2007

80. Moretti S, Pinzi C, Berti E, et al: In situ expression of transforming growth factor beta is associated with melanoma progression and correlates with Ki67, HLA-DR and beta 3 integrin expression. Melanoma Res 7: 313-321, 1997.

81. Piek E and Roberts AB: Suppressor and oncogenic roles of transforming growth factor- $\beta$ and its signaling pathways in tumorigenesis. Adv Cancer Res 83: 1-54, 2001.

82. Roberts AB and Wakefield LM: The two faces of transforming growth factor B in carcinogenesis. Proc Natl Acad Sci USA 100: 8621-8623, 2003.

83. Wang J, Sun L, Myeroff L, et al: Demonstration that mutation of the type II transforming growth factor beta receptor inactivates its tumor suppressor activity in replication error-positive colon carcinoma cells. J Biol Chem 270: 22044-22049, 1995.

84. Li C, Hampson IN, Hampson L, Kumar P, Bernabeu C and Kumar S: CD105 antagonizes the inhibitory signaling of transforming growth factor beta1 on human vascular endothelial cells. FASEB J 14: 55-64, 2000.
85. Lastres P, Letamendia A, Zhang H, et al: Endoglin modulates cellular responses to TGF-beta 1. J Cell Biol 133: 1109-1121, 1996.

86. Sánchez-Elsner T, Botella LM, Velasco B, Langa C and Bernabeu $\mathrm{C}$ : Endoglin expression is regulated by transcriptional cooperation between the hypoxia and transforming growth factor- $ß$ pathways. J Biol Chem 277: 43799-43808, 2002.

87. Dassoulas K, Gazouli M, Theodoropoulos G, et al: Vascular endothelial growth factor and endoglin expression in colorectal cancer. J Cancer Res Clin Oncol 136: 703-708, 2010.

88. Zvrko E, Mikic A, Vuckovic L, Djukic V and Knezevic M: Prognostic relevance of CD105-assessed microvessel density in laryngeal carcinoma. Otolaryngol Head Neck Surg 141: 478-483, 2009

89. Yoshitomi H, Kobayashi S, Ohtsuka M, Kimura F, Shimizu H, Yoshidome $\mathrm{H}$ and Miyazaki M: Specific expression of endoglin (CD105) in endothelial cells of intratumoral blood and lymphatic vessels in pancreatic cancer. Pancreas 37: 275-281, 2008.

90. Barresi V, Cerasoli S, Vitarelli E and Tuccari G: Density of microvessels positive for CD105 (endoglin) is related to prognosis in meningiomas. Acta Neuropathol 114: 147-156, 2007.

91. El-Gohary YM, Silverman JF and Olson PR: Endoglin (CD105) and vascular endothelial growth factor as prognostic markers in prostatic adenocarcinoma. Am J Clin Pathol 127: 572-579, 2007.

92. Dales JP, Garcia S, Andrac L, et al: Prognostic significance of angiogenesis evaluated by CD105 expression compared to CD31 in 905 breast carcinomas: correlation with long-term patient outcome. Int J Oncol 24: 1197-1204, 2004.

93. Koumoundourou D, Kassimatis T, Zolota V, et al: Prognostic significance of TGFbeta- 1 and $\mathrm{pSmad} 2 / 3$ in breast cancer patients with T1-2,N0 tumours. Anticancer Res 27: 2613-2620, 2007.

94. Hazelbag S, Kenter GG, Gorter A and Fleuren GJ: Prognostic relevance of TGF-beta1 and PAI-1 in cervical cancer. Int J Cancer 112: 1020-1028, 2004.

95. Ivanovic V, Todorovic-Rakovic N, Demajo M, NeskovicKonstantinovic Z, Subota V, Ivanisevic-Milovanovic O and Nikolic-Vukosavljevic D: Elevated plasma levels of transforming growth factor-beta 1 (TGF-beta 1) in patients with advanced breast cancer: association with disease progression. Eur J Cancer 39: 454-461, 2003.

96. Logullo AF, Nonogaki S, Miguel RE, et al: Transforming growth factor beta1 (TGFbeta1) expression in head and neck squamous cell carcinoma patients as related to prognosis. J Oral Pathol Med 32: 139-145, 2003.

97. Robson H, Anderson E, James RD and Schofield PF: Transforming growth factor beta 1 expression in human colorectal tumours: an independent prognostic marker in a subgroup of poor prognosis patients. Br J Cancer 74: 753-758, 1996.

98. Wagner AD, Arnold D, Grothey AA, Haerting J and Unverzagt S: Anti-angiogenic therapies for metastatic colorectal cancer. Cochrane Database Syst Rev 8: 1-78, 2009. 